\title{
Cytotoxicity and antiviral activity evaluation of Cymbopogon spp hydroethanolic extracts
}

\author{
Lisandra Chiamenti ${ }^{*}$, Francini Pereira da Silva², Karoline Schallemberger ${ }^{3}$, Meriane Demoliner ${ }^{4}$, \\ Caroline Rigotto ${ }^{5}$, Juliane Deise Fleck ${ }^{5}$
}

${ }^{1}$ Toxicology and Toxicological Analysis Post-Graduation Program, Feevale University, Novo Hamburgo, RS, Brazil, ${ }^{2}$ Virology Post-graduation Program, Feevale University, Novo Hamburgo, RS, Brazil, ${ }^{3}$ Biology student, Feevale University, Novo Hamburgo, RS, Brazil, ${ }^{4}$ Ambiental Quality Post-graduation Program, Feevale University, Novo Hamburgo, RS, Brazil,

${ }^{5}$ Molecular Microbiology Laboratory, Feevale University, Novo Hamburgo, RS, Brazil

\begin{abstract}
Cymbopogon citratus and C. nardus are noteworthy among the several existing plant species displaying medicinal properties, due to the potential pharmacological activity of these species, including antiviral, antibacterial, antifungal and anti-trypanosomal activities. The objective of this study was to carry out in vitro toxicity tests of plant extracts from both species and analyze potential antiviral activity against Human mastadenovirus serotype 5 (HAdV-5). Two cell lines (A549 and VERO) were used and mitochondrial and lysosomal viability were determined by the MTT and neutral red assay, respectively, after two exposure times ( 24 hours and six days). The aim of these assays was to counteract the behavior of the extracts against the different cell lines and determine their non-toxic concentration range, in order to evaluate possible antiviral activity against HAdV-5. Plaque reduction and inhibition index of viral titer assays were performed using the maximum non-cytotoxic concentrations (MNCC) of each extract. The results indicate MNCC at $625 \mu \mathrm{g} / \mathrm{mL}$ for all extracts, except for Cymbopogon nardus obtained with $80 \%$ ethanol (CN80), which showed toxicity at concentrations higher than $312.5 \mu \mathrm{g} / \mathrm{mL}$. CN80 was the only extract that displayed potential activity against HAdV-5, at a concentration of $75 \mu \mathrm{g} / \mathrm{mL}$, becoming a candidate for extract fraction purification and/or the isolation of substances related to the observed antiviral activity.
\end{abstract}

Keywords: Cymbopogon citratus/toxicity. Cymbopogon nardus/toxicity. Cellular viability. Human mastadenovirus. Plants/extracts.

\section{INTRODUCTION}

The Cymbopogon (Poaceae) genus is widely distributed worldwide and applied in popular medicine for different therapeutic purposes. Biological activities are closely related to their constituents, such as phenolic acids, flavonoids and alkaloids, among other secondary metabolites. In different countries, the popular use of species belonging to this genus indicates applicability as a tranquilizer, antiseptic, antipyretic, anti-inflammatory and analgesic compound and insect repellent, among others (Avoseh et al., 2015).

Cymbopogon citratus (CC), a species commonly known as "lemongrass", has been used in the pharma-

\footnotetext{
*Correpondence: L. Chiamenti. Feevale University, 2755, ERS-239

- Novo Hamburgo / RS - Brazil. Tel.: +55 51 35868800. E-mail:

lisandrachiamenti@gmail.com (iD)
}

ceutical, food, perfumery and cosmetic industries for various purposes (Soares et al., 2013; Ekpenyong, Akpan, 2017), while Cymbopogon nardus (CN), known as "citronella grass", has been used as an insect repellent due to its intense aroma (Oliveira et al., 2011). Several reports in the scientific literature of antibacterial (Ocheng et al., 2014), antifungal (Oliveira et al., 2011) and antitrypanosomal (Kpoviessi et al., 2014) activities are available.

Furthermore, these species have also been evaluated concerning possible antiviral activity. Some studies have demonstrated ethanolic extract $\mathrm{CN}$ activity against herpes simplex virus serotype 1 (HSV-1) (Adibah, Nazlina, Ahmad, 2010), as well as against measles using hexaneextracted fractions (Nurul Aini et al., 2006; Linton, Jerah, Bin Ahmad, 2013). In addition, the antiviral action of $\mathrm{CC}$ has been reported for its methanolic extract against dengue virus serotype 1 (Tang et al., 2012), and for 
its essential oil against HSV-1 (Minami et al., 2006; AbuShady et al., 2017), hepatitis A virus (AbuShady et al., 2017) and murine norovirus (Gilling et al., 2014; Kim et al., 2017).

Human mastadenovirus (HAdV) are worldwide distributed pathogens, with endemic characteristics in most regions. Currently, 67 HAdV serotypes are known, subdivided into seven species (named A-G), included in the Mastadenovirus genus of the Adenoviridae family (ICTV, 2017). Human mastadenovirus serotype 5 (HAdV5 ) is the most studied, responsible for several diseases, including acute respiratory infection, gastroenteritis, hepatitis, keratoconjunctivitis, meningoencephalitis, myocarditis and pneumonia, among others (AlonsoPadilla et al., 2016). Likewise, these pathogens are also involved in serious and frequent complications in transplanted and immunocompromised patients (AlonsoPadilla et al., 2016; Grim, Reid, Clark, 2017). There is no specific treatment for $\mathrm{HAdV}$, and the prospection of new drugs with antiviral action against this agent remains relevant. Considering this information, this study aimed to evaluate the cytotoxicity and potential activity against HAdV-5 of CC and CN hydroethanolic extracts.

\section{MATERIAL AND METHODS}

\section{Plant material}

The aerial portions of $\mathrm{CC}$ and $\mathrm{CN}$ specimens were collected in the cities of Novo Hamburgo (coordinates: latitude -29.6773586, longitude -51.11321008) and Santa Maria do Herval (coordinates: latitude -29.49666672, latitude -50.97277024), respectively, in the state of Rio Grande do Sul, located in southern Brazil. Both species were collected in August 2016 and identified by professor and botanist Rage Maluf. After identification, the specimens were dried in a circulating air incubator for ten days and subsequently comminuted. Species exsicates were obtained and are deposited at the botanical collection belonging to the Feevale University Botany Laboratory, under the numbers $450(\mathrm{CN})$ and $451(\mathrm{CC})$.

\section{Extraction}

The extracts were prepared in two ways: dynamic maceration for 8 hours, in constant agitation, with $60 \%$ and $80 \%$ ethanol; and static maceration for 7 days with $60 \%$ ethanol. The raw vegetal materials (RVM) were remacerated, using the same conditions as the initial extraction process. Therefore, the processes resulted in six different extracts: CC60 and CN60 (extracted with 60\% ethanol by dynamic maceration), CC80 and CN80 (80\% ethanol, by dynamic maceration), CC607d and CN607d ( $60 \%$ ethanol, by static maceration for 7 days).

Extracts were then filtered and ethanol was removed under reduced pressure in a rotary evaporator, resulting in an aqueous residue, which was frozen and then freezedried for five days. Samples were then weighed and stored in amber vials, in a desiccator and at room temperature. The extract yields were calculated by the formula: Yield $(\%)=($ mass of the extract/mass of the dried plant material $)$ x 100 (Fu et al., 2016).

\section{Phytochemical characterization}

\section{Qualitative analyses}

Extracts were submitted to preliminary phytochemical screening to detect the main classes of secondary metabolites, based on the methodologies described by Costa (2001). Approximately $10 \mathrm{~g}$ of RVM of each plant were used to detect phytochemicals through qualitative tests, involving precipitation reactions or color development, allowing for the detection of the presence of groups of metabolites.

The results of these analyses were confirmed by thin layer chromatography, according to Wagner and Bladt (1996). Aluminum chromate sheets (Silica gel 60 , layer $0.20 \mathrm{~mm}$, Alugram ${ }^{\circledR}$ Sil G, Mashery-Nagel, Düren, Germany) were used, followed by different eluting systems, i.e. ethyl acetate/formic acid / water (80:10:10), ethyl acetate/formic acid/glacial acetic acid/ water (100:11:11:27), acetone/toluene/formic acid (3:3:1) and chloroform/glacial acetic acid/methanol/water (64:32:12:8). Chromatograms were visualized under ultraviolet light ( 254 and $365 \mathrm{~nm}$ ) before and after being sprayed with the respective chromogenic reagents.

\section{Quantitative analyses}

Analyses were carried out or the quantification of total polyphenols, total tannins and total flavonoids. All procedures were performed under light and in triplicate. Results were expressed as means \pm standard deviation (SD).

\section{Total polyphenols}

Total polyphenols were spectrophotometrically determined by the Folin-Ciocalteu method, as described in the European Pharmacopoeia, with minor modifications (Verza et al., 2007). A solution was prepared with $2 \mathrm{~mL}$ of each extract previously diluted in water, $2 \mathrm{~mL}$ of FolinCiocalteu reagent, $10 \mathrm{~mL}$ of water in a $25 \mathrm{~mL}$ volumetric flask, and the volume was made up with a saturated sodium 
carbonate solution $\left(\operatorname{Synth}^{\circledR}\right)$. The obtained solution was left to react for $30 \mathrm{~min}$ and the absorbance reading was performed at $760 \mathrm{~nm}$. The reaction blank was obtained by replacing the sample volume with water, maintaining the same amounts of Folin-Ciocalteu reagent and sodium carbonate solution. Quantification was performed by means of an analytical curve obtained from the measurement of the absorbances of known concentrations of pyrogallol ( $\mathrm{r}=0.9994)$ (Sigma-Aldrich $\left.{ }^{\circledR}\right)$. The results were expressed as $\mathrm{mg} / \mathrm{g}$ extract pyrogallol equivalents.

\section{Total tannins}

Initially, $400 \mathrm{mg}$ of powdered casein $\left(\operatorname{Synth}^{\circledR}\right)$ were added to an approximately $1 \mathrm{mg} / \mathrm{mL}$ of each extract solution diluted in distilled water, which was maintained under magnetic stirring for 1 hour. Subsequently, the sample was filtered through qualitative filter paper (weight $80 \mathrm{~g} / \mathrm{m}^{2}$, Unifil $^{\circledR}$ ) and an aliquot of the filtrate was removed and diluted in water to determine residual phenols, as per the aforementioned subitem above. Reading wavelength, reading time, reagent quantity and quantification parameters were also set according to total polyphenols.

\section{Total flavonoids}

Total flavonoids were spectrophotometrically determined according to Woisky and Salatino (1998). A solution was prepared with $2 \mathrm{~mL}$ of each extract previously diluted in $20 \mathrm{~mL}$ of methanol and $1 \mathrm{~mL}$ of a $5 \%$ aluminum chloride solution (w/v) in a $50 \mathrm{~mL}$ volumetric flask and the volume made up filled with methanol. The absorbance was determined at $425 \mathrm{~nm}$ after $30 \mathrm{~min}$ of reagent addition. Quantification was performed using an analytical curve obtained from the absorbance measure of known concentrations of quercetin (Sigma-Aldrich ${ }^{\circledR}$ ) $(\mathrm{r}=0.9999)$. The results were expressed as $\mathrm{mg} / \mathrm{g}$ extract quercetin equivalent.

\section{Cell culture}

For the cytotoxicity evaluations, A549 cells, originated from human lung adenocarcinoma cell line, and VERO cells, derived from African green monkey kidney were used. These cell lines were used for toxicity comparisons, since A549 is a tumoral and permissive line for HadV infection and VERO is non-tumoral cell line, frequently used for toxicity prospection, since the renal route is the main xenobiotic excretion route. In this way, it was possible to counteract the behavior of the extracts against these different cell lines. Both cell lines belongs to the Feevale University Molecular Microbiology Laboratory inventory.
Cells were cultured in minimal essential medium (MEM) supplemented with $10 \%$ fetal bovine serum (FBS). Cultures were maintained at $37^{\circ} \mathrm{C}$ in a humid atmosphere at $5 \% \mathrm{CO}_{2}$ in a half-open system (standard conditions) (SC), and trypsinization was used for cell maintenance.

\section{Cytotoxicity evaluations}

For treatment with the extracts, cells were seeded into 96-well microplates at a density of approximately $1.5 \times 10^{5}$ and incubated for 24 hours under SC. After $24 \mathrm{~h}$, culture medium was replaced with different extract serial dilutions (4.88 to $5000 \mu \mathrm{g} / \mathrm{mL}$ ) diluted in MEM and re-incubated. Acute toxicity was assessed at 24 hours and chronic toxicity, after six days of exposure, after which the specific dyes and protocols for each assay were used. Cells maintained under SC were used as negative control, and $10 \mu \mathrm{L}$ of a $1 \%$ hydrogen peroxide $\left(\mathrm{H}_{2} \mathrm{O}_{2}\right)$ solution was used as positive control (cell death), added 2 hours prior to addition of the cytotoxicity dyes to two untreated cell wells.

In order to evaluate cytotoxicity by the mitochondrial viability parameter, the 3- [4,5-dimethylthiazol-2-yl]-2,5diphenyltetrazolium bromide (MTT) assay was performed as standardized at the Feevale University Cytotoxicity Laboratory, according to Mosmann (1983) and Fotakis and Timbrell (2006). Briefly, after the exposure periods, the culture medium was carefully removed and MTT $\left(4 \mu \mathrm{L} / \mathrm{mL}\right.$ per well) (Sigma Aldrich $\left.{ }^{\circledR}\right)$ diluted in MEM was added. The plate was then wrapped in foil paper to prevent dye degradation and again incubated under $\mathrm{SC}$ for $2 \mathrm{~h}$, while metabolically active cells reduced MTT to formazan blue crystals. After incubation, the medium was removed by inversion and $100 \mu \mathrm{L}$ of dimethyl sulfoxide (DMSO) was added to each well for crystal solubilization. The absorbances were determined at $570 \mathrm{~nm}$ using a microplate spectrophotometer (M3, Molecular Devices ${ }^{\circledR}$ ).

The neutral red (NR) incorporation method was conducted to assess cytotoxicity through lysosome viability, following a protocol previously standardized at the Feevale University Cytotoxicity Laboratory, according to Borenfreund and Puerner (1985). Briefly, after exposure, the culture medium was removed and $100 \mu \mathrm{L}$ of NR $(50 \mu \mathrm{g} / \mathrm{mL})\left(\right.$ Sigma Aldrich $\left.^{\circledR}\right)$ diluted in MEM was added to each well. After three hours of incubation at SC, the medium was removed and cells were washed with a buffered saline solution (PBS), fixative solution $\left(1 \% \mathrm{CaCl}_{2}\right.$ in $0.5 \%$ formaldehyde) and dye solubilization solution ( $1 \%$ acetic acid in 50\% ethanol). Plates were then gently shaken for 10 minutes and absorbances were determined at $540 \mathrm{~nm}$ using a microplate spectrophotometer (M3, Molecular Devices $\left.{ }^{\circledR}\right)$. 
The results obtained by these assays were expressed as percentage relative to the mean of the negative control (cultures maintained in standard medium, considered as $100 \%$ viable). The percentages calculated for the different sample concentrations were plotted and the mean cytotoxic concentration values $\left(\mathrm{CC}_{50}\right)$ were estimated by a linear regression analysis. Only CC60 after 6 days of exposure in the MTT assay exhibited different behavior, where a 3-order polynomial regression was required. The calculated values represent the means of two independent experiments \pm SD.

\section{Statistical analyses}

The SPSS 24 software (SPSS for Windows) was used for all statistical analyses. An ANOVA test with posthoc (contrast analysis) was applied to test the differences between the types of extracts within the same sample. A paired t-test for dependent samples was used to verify if the concentration values for the same extract differed between the $24 \mathrm{~h}$ and 6-day exposure periods, while a paired t-test for independent samples was used to verify whether these values differed between the evaluated cell lines.

\section{Viral stock}

The virus used in this study, HAdV-5, belongs to the viral inventory of the Feevale University Molecular Microbiology Laboratory. For the production of the viral suspensions, $1 \mathrm{~mL}$ of HAdV-5 was inoculated into a cell culture bottle with a confluent A549 cell monolayer. After viral infection, when lysis was observed in $80 \%$ of the cell monolayer, the infected bottle was exposed to freezing $\left(-80^{\circ} \mathrm{C}\right)$ and thawing cycles (ambient temperature), in order to release the viral particles retained inside the cells. The viral suspension stock was then aliquoted and stored in ultra-freezer at $-80^{\circ} \mathrm{C}$. Titration was carried out on the basis of plaque forming unit (PFU) count by the plaque assay (Burleson, Chambers, Wiedbrauk, 1992).

\section{Antiviral assays}

The plaque reduction assay was performed using a protocol previously standardized at the Molecular Microbiology Laboratory (Feevale University), as described by Burleson, Chambers and Wiedbrauk (1992). Briefly, A549 cells were seeded in 6-well microplates at a density of approximately $1.5 \times 10^{5}$ and incubated under SC for 24 hours. Then, $500 \mu \mathrm{L}$ of the viral inoculum (100 infective doses) were added to the confluent cell monolayers; plates were re-incubated for 1 hour and gently shaken every 15 minutes for viral adsorption. Subsequently, the viral inoculum was removed and a semi-solid overlay containing DMEM 2x (Dubelco's Modified Eagle's Medium), Bacto agar and three decreasing concentrations $(600,150$ and $75 \mu \mathrm{g} / \mathrm{mL})$ of each extract, except for CN80 $(300,150$ and $75 \mu \mathrm{g} / \mathrm{mL}$ ), was added. The control samples consisting of virus-infected untreated or treated cells were also included in each assay. Plates were maintained for six days in SC with daily observation. After this period, the overlay was removed and cell monolayers were stained with a crystal violet solution, where non-stained lesions (plaques) were quantified and compared to the viral control. The mean inhibitory concentration $\left(\mathrm{IC}_{50}\right)$ was determined by two independent assays. The percentage of viral inhibition was calculated by IP $=[1$ - (number of test plates / number of control plates) $]$ x 100 and the general selectivity index (SI) by $\mathrm{SI}=\left(\mathrm{CC}_{50}\right) /\left(\mathrm{IC}_{50}\right)$.

Evaluation of the viral titer inhibition index was carried out using a protocol standardized in the Feevale University Molecular Microbiology Laboratory, according to Atkinson (1961), using the TCID $_{50}$ (tissue culture infection dose) unit. For this, A549 cells were seeded at a concentration of $0.7 \times 10^{5}$ cells $/ \mathrm{mL}$ in $96-w e l l$ microplates, incubated under SC for $1 \mathrm{~h}$ and then exposed to 10 -fold serial HAdV-5 dilutions $\left(10^{-2}\right.$ to $\left.{ }^{-9}\right)$. Microplates were re-incubated for $1 \mathrm{~h}$ and the extracts were then added to the MNCC $(600 \mu \mathrm{g} / \mathrm{mL}$ were used for all extracts except $\mathrm{CN} 80$, where $300 \mu \mathrm{g} / \mathrm{mL}$ was used), in quadruplicate. Viral titration of each dilution and negative control (untreated and non-infected cells) were performed for each plate. After 5 days of incubation, plates were observed under an inverted microscope and the viral titers $\left(\mathrm{TCID}_{50} / \mathrm{mL}\right)$ were calculated.

\section{RESULTS AND DISCUSSION}

In this study, two species belonging to the Cymbopogon genus were used for cytotoxicity determinations and evaluation of potential antiviral activity. Three different extracts were obtained for each plant species, all of which were used for assays, in order to investigate any antiviral potential for possible use in the treatment of infections caused by HAdV-5, displaying low toxicity.

Initially, extractions were carried out and the yields of the freeze-dried extracts were calculated, ranging from 21.2 to $25.26 \%$. This information is important to verify if types of maceration and ethanol concentration influenced the extraction of the compounds, which were later characterized. 
A preliminary phytochemical analysis allows for the characterization of classes of secondary metabolites of pharmacological interest present in RVM, which are useful as a starting point for subsequent biological activity tests (Soares et al., 2013). The presence of steroids, triterpenes, tannins and flavonoids was observed for both extracts through qualitative analyses. Previous studies have reported such substances for both assessed species (Soares et al., 2013).

Moreover, a quantitative evaluation of extract composition identified different amounts of phytoconstituents (Table I). Generally, CC extracts presented higher values for all tested constituents, except CC607D, in which which lower polyphenol and total tannin values were observed when compared to CN607d. Individually, extract CC60 presented higher polyphenol, tannin and total flavonoid values, while lower values were noted for CN60. Kumar et al. (2012) reported similar results while quantifying total polyphenols in methanolic extracts obtained from these species, with higher values determined for CC (15.73 GAE $/ \mathrm{mL})$ compared to $\mathrm{CN}(9.1$ $\mathrm{GAE} / \mathrm{mL}$ ). On the other hand, $15 \mathrm{TAE} / \mathrm{mL}$ of total tannins were quantified in the $\mathrm{CC}$ methanolic extract, comparable to results found for CC607d and CC80 (Panseira et al., 2003).

Phytoconstituents posssess their own physicochemical interactions and are eventually released according to the solvent and solvent concentration, contact surface between extractor liquid and RVM, extraction time, RVM granulometry, saturation, metabolite stability, eluent polarity and constituent oxidation, among others, generating differences among extractions. Thus, it is interesting to perform experiments with different sample preparations in order to identify different constituent profiles (Mojzer et al., 2016).

The plant extracts caused alterations in both cytotoxicity assays, suggesting that substances present in the extracts interfered with cell function (Figure 1). In general, the two tests showed similar results. Decreased cell viability (approximately 90\%) was observed with the use of the positive control (data not shown). $\mathrm{CC}_{50}$ values of the hydroethanolic extracts were determined by two independent experiments, each in triplicate. These indicated toxicity levels and allowed for the SI calculation of the extracts against the antiviral assays.

Table II displays the statistically significant differences between extracts in both cell lines. No significant differences were found between the $24 \mathrm{~h}$ and 6-day exposures in A549 cells, dissimilar from VERO cells, in which a difference between some extracts was observed when comparing MTT exposures. In general, no selectivity for any cell line was observed.

The limitations of cytotoxicity assays through cell viability are not fully elucidated (Riss et al., 2004). To reduce the odds of over- or underestimating toxicity and confirm the values obtained herein, two assays (with different target organelles), two exposure periods and two cell lines were chosen. In general, CN80 was shown to be the most toxic extract, with the lowest $\mathrm{CC}_{50}$ values among all exposures and lineages, with the exception of A549 in the MTT assay after 6 days od exposure.

Although other authors use different measures to estimate the cytotoxic values of their extracts, it is possible to infer the toxicity of these extracts for comparison. ElNabi, El-Garawani and El-Berry (2016) used aqueous CC extract sand determined the $\mathrm{CC}_{50}$ at $630 \mu \mathrm{g} / \mathrm{mL}$ applying the NR assay to hepatocarcinoma cells (HepG2). In addition, $\mathrm{CN}$ fractions extracted with hexane presented $\mathrm{CC}_{50}$ of 469 $\mu \mathrm{g} / \mathrm{mL}$ (Abdibah, Nazlina, Ahmad, 2010), whereas CC fractions using the same solvent presented $\mathrm{CC}_{50} 300 \mu \mathrm{g} / \mathrm{mL}$ (Nurul Aini et al., 2006), using both the MTT protocol and VERO cells. No reports of cytotoxicity for hydroethanolic extracts of the Cymbopogon species tested herein were reported, but it is possible to infer that the compounds extracted by hexane presented higher toxicity. However, all $\mathrm{CC}_{50}$ values determined in the present study are higher

Table I - Quantification of phytoconstituints

\begin{tabular}{lccc}
\hline & Total polyphenols (EP/g) & Total tannins (EP/g) & Total Flavonoids (EQ/g) \\
\hline CC60 & $35.25 \pm 0.07$ & $29.71 \pm 0.06$ & $25.77 \pm 0.02$ \\
CN60 & $8.37 \pm 0.07$ & $4.92 \pm 0.07$ & $11.07 \pm 0.02$ \\
CC607D & $18.84 \pm 0.1$ & $12.41 \pm 0.13$ & $19.44 \pm 0.02$ \\
CN607D & $20.09 \pm 0.05$ & $13.14 \pm 0.2$ & $14.37 \pm 0.07$ \\
CC80 & $28.19 \pm 0.03$ & $16.68 \pm 0.07$ & $24.83 \pm 0.03$ \\
CN80 & $17.51 \pm 0.04$ & $11.58 \pm 0.06$ & $12.98 \pm 0.02$ \\
\hline
\end{tabular}

Values expressed as mean \pm standard deviation obtained with triplicates. Results of total polyphenols and total tannins expressed as pyrogallol equivalent $\mathrm{mg} / \mathrm{g}$ extract $(\mathrm{EP} / \mathrm{g})$ and total flavonoids as quercetin equivalent $\mathrm{mg} / \mathrm{g}$ extract $(\mathrm{EQ} / \mathrm{g})$. 

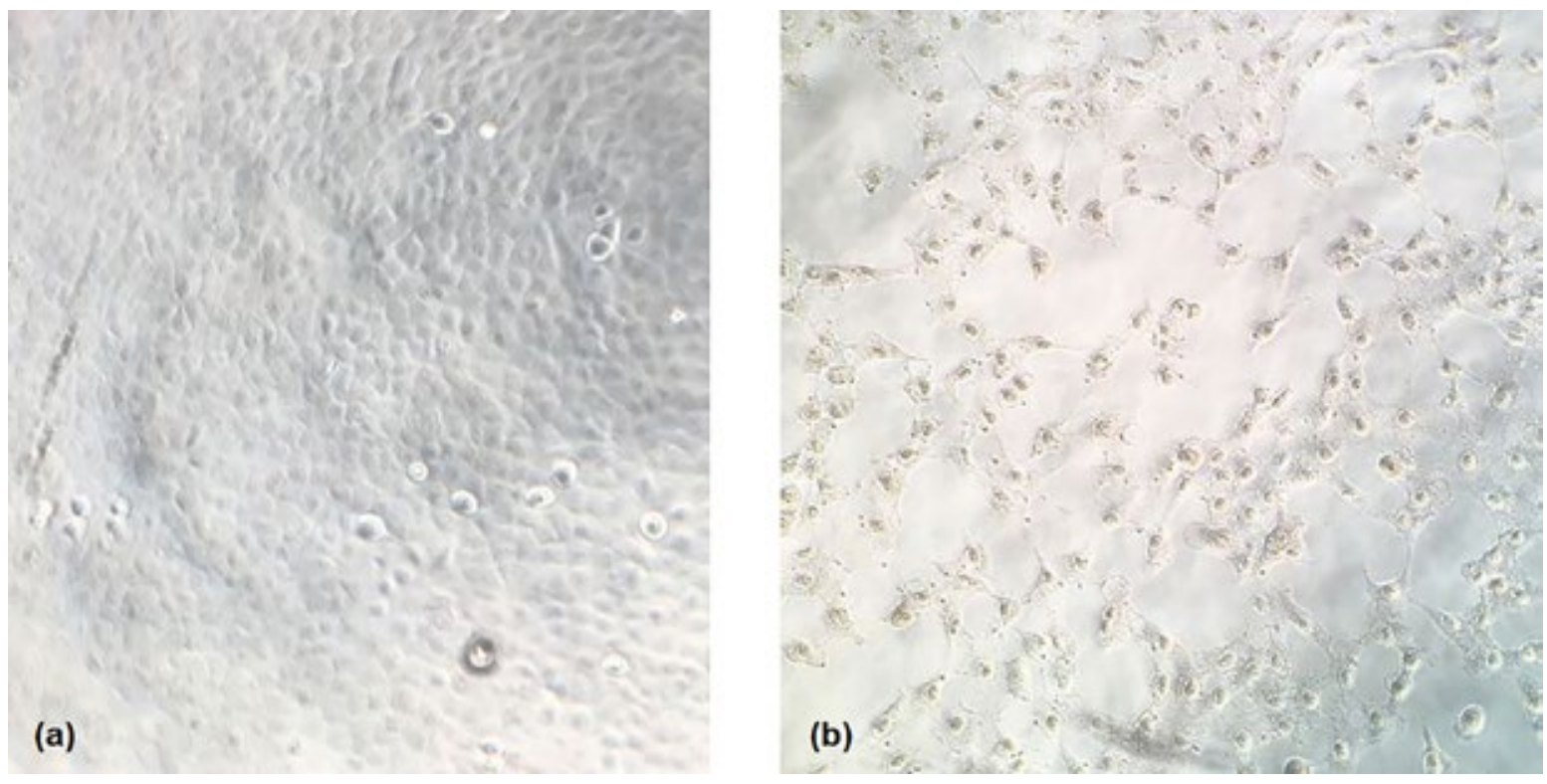

FIGURE 1 - Monolayer sheet of untreated and treated A549 cells. (a) The normal cells were polygonal with well-defined and complete monolayer (untreated cells, negative control). (b) Cells treated with large concentrations of extracts did not form a complete monolayer and tends to appear tense cytoplasm, black nuclei in the centre. The cells were observed after 6 days at SC and under inverted microscope at $200 \times$ magnification.

TABLE II - $\mathrm{CC}_{50}$ of the extracts against A549 and VERO cells, using the MTT and NR protocols

\begin{tabular}{|c|c|c|c|c|}
\hline \multicolumn{5}{|c|}{ A459 } \\
\hline \multirow{2}{*}{ Extracts } & \multicolumn{2}{|c|}{ MTT } & \multicolumn{2}{|c|}{ NR } \\
\hline & $24 \mathrm{~h}(* *)$ & 6 days & $24 \mathrm{~h}(* *)$ & 6 days $(* *)$ \\
\hline $\mathrm{CC} 60$ & $3332 \pm 496$ & $2384 \pm 433$ & $3471 \pm 158$ & $2653 \pm 11(\mathrm{a})$ \\
\hline CC607D & $2806 \pm 46$ & $2181 \pm 81$ & $2838 \pm 186$ & $2486 \pm 332$ \\
\hline $\mathrm{CC} 80$ & $3740 \pm 117(\mathrm{a}, \mathrm{c})$ & $2626 \pm 16(a)$ & $3615 \pm 269$ & $3865 \pm 4(a, b)$ \\
\hline CN60 & $2650 \pm 75(a, b)$ & $2351 \pm 107$ & $2898 \pm 153$ & $2269 \pm 177$ \\
\hline CN607D & $4660 \pm 147(b, c)$ & $3279 \pm 502$ & $2543 \pm 25(\mathrm{a})$ & $2289 \pm 80$ \\
\hline CN80 & $2305 \pm 407$ & $2341 \pm 21(\mathrm{a})$ & $1783 \pm 44$ (a) & $1728 \pm 100(b)$ \\
\hline \multicolumn{5}{|c|}{ VERO } \\
\hline \multirow{2}{*}{ Extracts } & \multicolumn{2}{|c|}{ MTT } & \multicolumn{2}{|c|}{ NR } \\
\hline & $24 \mathrm{~h}(* *)$ & 6 days & $24 \mathrm{~h}$ & 6 days \\
\hline$\overline{\mathrm{CC} 60}$ & $3902 \pm 86(\mathrm{a}, \mathrm{c}, \mathrm{X})$ & $1883 \pm 93(\mathrm{X})$ & $2003 \pm 175$ & $3236 \pm 762$ \\
\hline CC607D & $2466 \pm 181$ & $1882 \pm 216$ & $2037 \pm 394$ & $2411 \pm 61$ \\
\hline $\mathrm{CC} 80$ & $3833 \pm 58(\mathrm{~b}, \mathrm{Y})$ & $1924 \pm 220(\mathrm{Y})$ & $2073 \pm 53$ & $2730 \pm 273$ \\
\hline CN60 & $2338 \pm 120(a, b)$ & $2035 \pm 19$ & $2211 \pm 601$ & $2227 \pm 234$ \\
\hline CN607D & $3338 \pm 183(\mathrm{Z})$ & $1773 \pm 33(\mathrm{Z})$ & $1930 \pm 243$ & $2667 \pm 460$ \\
\hline $\mathrm{CN} 80$ & $2251 \pm 45(\mathrm{a}, \mathrm{b}, \mathrm{c})$ & $1692 \pm 107$ & $1759 \pm 24$ & $1745 \pm 400$ \\
\hline
\end{tabular}

Values are the mean of duplicates \pm standard deviation. $\left({ }^{* *}\right) \mathrm{p}<0.001$. ANOVA between Games-Howell post-hoc extracts, where the lower-case letters are the same, there is a significant difference $p \leq 0.05$. Paired $T$ test between exposures, where the upper-case letters are the same, there is significant difference $\mathrm{p} \leq 0.05$.

than those reported in the literature, which may be due to different sets of extracted compounds, as hexane extracts more lipophilic compounds, while water and ethanol extract more hydrophilic ones (Cos et al., 2006). 
Cytotoxicity assessments prior to performing antiviral evaluations are indispensable to define the concentration limits to be used in the next step, following the prerogative that a useful substance should demonstrate minimal toxicity against the host (Di Nunzio et al., 2017). Changes in the cell surface or organelle membranes gradually become irreversible, resulting in decreased dye uptake and binding, used to distinguish dead and/ or damaged cells from living cells, which is the basis of cytotoxicity tests (Riss et al., 2004). These parameters should be evaluated as early as possible, as $30 \%$ of drug candidates fail due to their toxic effects (Kola, Landis, 2004)

Antiviral activity against $\mathrm{HAdV}-5$ propagated in the A549 cell culture was evaluated through the use of plaque reduction and inhibition index assays. The MNCC values obtained in the chronic exposure assay using the A549 cell line were used to calculate both indices, which is permissive to $\mathrm{HAdV}-5$. All extracts presented MNCC at $625 \mu \mathrm{g} / \mathrm{mL}$, except for CN80, with an MNCC at 312.5 $\mu \mathrm{g} / \mathrm{mL}$. The higher toxicity of this extract is also reflected in its $\mathrm{CC}_{50}$ values, which were the lowest values in almost all the evaluations.

Regarding the results of the antiviral assays, CN80 demonstrated mean inhibition of approximately 30 and $60 \%$ at 150 and $75 \mu \mathrm{g} / \mathrm{mL}$, respectively, in the plaque reduction assay. This allowed for the calculation of the $\mathrm{IC}_{50}$ for this extract, which would be obtained with 90 $\mu \mathrm{g} / \mathrm{mL}$. The $\mathrm{IC}_{50}$ value recommended for plant extracts against infectious diseases is $<100 \mu \mathrm{g} / \mathrm{mL}$ (Cos et al., 2006). The SI was 22.06, considered as presenting high activity against viruses (Karimi et al., 2016). On the contrary of what was expected (dose-dependent inhibition), the highest inhibition occurred at the lowest concentration. Given that this is a crude extract and, therefore, contains a high amount of substances, this behavior may be related to its toxicity which, despite being tested from MNCC, could still present a certain amount of toxicity to the cell culture at higher concentrations, preventing antiviral activity. In the inhibition index assay, mean inhibition of $1 \log _{10}$ was observed in three independent experiments, which is considered as low concerning antiviral activity (Kovac et al., 2012). This assay was carried out only at one extract concentration (MNCC). Thus, this result may be attributed to the same reason described above. However, this was the only extract that demonstrated inhibition activity in this assay, supporting possible action against the virus.

Despite the relationship between flavonoid content and antiviral activity against several pathogens, when phytochemicals are at high levels, toxicity induction may ocurr (Tang et al., 2012). This fact can be noted in the present study, where a greater amount of flavonoids was detected in the CC60 extract, but antiviral activity was observed only for CN80.

Results indicate a moderate inhibition $(>50 \%$ and $<90 \%$ ) (Schnitzler et al., 2010) of the CN80 extract, which is a promising outcome, while the other extracts presented no antiviral activity, except $\mathrm{CN} 607 \mathrm{~d}$, which led to a mean decrease in viral titer of $12 \%$ at the lowest concentration $(75 \mu \mathrm{g} / \mathrm{mL})$ in the plaque assay, thus not being considered an adequate candidate for subsequent tests.

These negative results differ from those reported in previous studies with these plant species. Divergences may be related to several variables, such as (1) variations in the concentrations of secondary metabolites present in the plants, related to factors that may influence compound extractions (discussed above); (2) the chemical structure of these metabolites; (3) the fact that the phytochemical mechanism of action on the interaction capacity with the virus is different for each pathogen (Carvalho et al., 2013); and (4) the possibility of synergism or antagonism between extracted compounds (Cos et al., 2006; Kumar, Pandey, 2013). The aim of this study was not to investigate the constituents or their relationships that could be responsible for the observed effects, both in the cytotoxicity assays and in the antiviral activity trials. However, in view of the various possible causes for the results found, a study with this purpose shall be carried out by our research group.

Accordingly, it is concluded that the $\mathrm{CN} 80$ extract was the only extract to demonstrate potential antiviral activity, since the plaque assays evaluated at $75 \mu \mathrm{g} / \mathrm{mL}$ were promising (60\% inhibition, with an SI of 22.06). Thus, isolation, purification and characterization of the active compounds of this extract should be carried out. Furthermore, investigations into the mechanism of action of the active compounds should be carried out, in order to provide further insights into inhibition adsorption and replication.

\section{ACKNOWLEDGMENTS}

This work was supported by Feevale University and CAPES Foundation, Ministry of Education of Brazil, Brasília, DF, Brazil.

\section{REFERENCES}

AbuShady EAE, Aly KAS, Azza MS, ElMokadem GMT, Abo-Ghalia HH. The antiviral and antioxidant activity of some medicinal plants. W J Pharm Sci. 2017;6(11):263-281. 
Adibah, AB, Nazlina I, Ahmad IB. Anti-HSV-1 activity of Cymbopogon nardus (L.) rendle fractions. Malays Appl Biol J. 2010;39(2):19-23.

Alonso-Padilla J, Papp T, Kaján GL, Benkő M, Havenga M, Lemckert A, et al. Development of novel adenoviral vectors to overcome challenges observed with HAdV-5-based constructs. Mol Ther. 2016;24(1):6-16.

Atkinson GF. The Spearman-karber method of estimating 50\% endpoints. Biometrics; 1961, n. BU-141-M.

Avoseh O, Oyedeji O, Rungqu P, Nkeh-Chungag B, Oyedeji A. Cymbopogon species; ethnopharmacology, phytochemistry and the pharmacological importance. Molecules. 2015;20(5):743853.

Borenfreund E, Puerner JA. Toxicity determined in vitro by morphological alterations and neutral red absorption. Toxicol Lett. 1985;24(2-3):119-24.

Burleson FG, Chambers TM, Wiedbrauk DL. Techniques for assessing antiviral agents. In: Burleson FG (editor). Virology a laboratory manual. California: Academic Press; 1992.

Carvalho OV, Oliveira FS, Saraiva GL, Botelho CV, Ferreira HCC, Santos MR, Silva Jr A, Almeida MR. Potencial antiviral da quercetina sobre o parvovírus canino. Arq Bras Med Vet Zootec. 2013;65(2):353-358.

Costa AF. Farmacognosia, vol. I, II. Lisboa: Fundação Calouste Gulbenkian; 2001.

Cos P, Vlietinck AJ, Berghe DV, Maes L. Anti-infective potential of natural products: how to develop a stronger in vitro 'proof-ofconcept'. J Ethnopharmacol. 2006;106(3):290-302.

Di Nunzio M, Valli V, Tomás-Cobos L, Tomás-Chisbert T, Murgui-Bosch L, Danesi F, Bordoni A. Is cytotoxicity a determinant of the different in vitro and in vivo effects of bioactives? BMC Complement Altern Med. 2017;17(1):453.

El-Nabi SH, El-Garawani I, El-Berry A. The apoptotic properties of Cinnamomum zeylanicum and Cymbopogon citratus on human hepatocellular carcinoma cell line (HepG2). Eur J Phar Med Res. 2016;3(9):44-48.

Ekpenyong CE, Akpan EE. Use of Cymbopogon citratus essential oil in food preservation: Recent advances and future perspectives. Crit Rev Food Sci Nutr. 2017;57(12):2541-2559.
Fotakis G, Timbrell JA. In vitro cytotoxicity assays: comparison of LDH, neutral red, MTT and protein assay in hepatoma cell lines following exposure to cadmium chloride. Toxicol Lett. 2006;160(2):171-7.

Fu Z, Tu Z, Zhang L, Wang H, Wen Q, Huang T. Antioxidant activities and polyphenols of sweet potato (Ipomoea batatas L.) leaves extracted with solvents of various polarities. Food Biosci. 2016;15:11-8.

Gilling DH, Kitajima M, Torrey JR, Bright KR. Mechanisms of antiviral action of plant antimicrobials against murine norovirus. Appl Environ Microbiol. 2014;80(16):4898-910.

Grim SA, Reid GE, Clark NM. Update in the treatment of noninfluenza respiratory virus infection in solid organ transplant recipients. Expert Opin Pharmacother. 2017;18(8):767-779.

ICTV, 2017. The Classification and Nomenclature of Viruses: The Online (10th) Report of the International Committee on Taxonomy of Viruses. Available in https://talk.ictvonline.org/ ictv-reports/ictv_online_report/.

Karimi A, Moradi MT, Alidadi S, Hashemi L. Anti-adenovirus activity, antioxidant potential, and phenolic content of black tea (Camellia sinensis Kuntze) extract. J Complement Integr Med. 2016;13(4):357-363.

Kim YW, You HJ, Lee S, Kim B, Kim DK, Choi JB et al. Inactivation of norovirus by lemongrass essential oil using a norovirus surrogate system. J Food Prot. 2017;80(8):1293-1302.

Kola I, Landis J. Can the pharmaceutical industry reduce attrition rates? Nat Rev Drug Discov. 2004;3(8):711-5.

Kovač K, Diez-Valcarce M, Raspor P, Hernández M, RodríguezLázaro D. Natural plant essential oils do not inactivate nonenveloped enteric viruses. Food Environ Virol. 2012;4(4):20912.

Kpoviessi S, Bero J, Agbani P, Gbaguidi F, Kpadonou-Kpoviessi B, Sinsin B, Accrombessi G, Frédérich M, Moudachirou M, Quetin-Leclercq J. Chemical composition, cytotoxicity and in vitro antitrypanosomal and antiplasmodial activity of the essential oils of four Cymbopogon species from Benin. J Ethnopharmacol. 2014;151(1):652-9

Kumar V, Kumar U, Mishra M, Prakash V. In vitro antioxidants status in selected Indian medicinal plants. Int J Pharm Bio. 2012;3(4):511-520. 
Kumar S, Pandey AK. Chemistry and biological activities of flavonoids: an overview. Scient World J. 2013;2013:162750.

Linton REA, Jerah SL, Bin Ahmad I. The effect of combination of octadecanoic acid, methyl ester and ribavirin against measles virus. Int J Sci Tech Res. 2013;2(10):181-184.

Minami M, Kita M, Nakaya T, Yamamoto T, Kuriyama H, Imanishi J. The inhibitory effect of essential oils on herpes simplex virus type-1 replication in vitro. Microbiol Immunol. 2003;47(9):681-684.

Mojzer EB, Hrnčič MK, Škerget M, Knez Ž, Bren U. Polyphenols: extraction methods, antioxidative action, bioavailability and anticarcinogenic effects. Molecules. 2016;21(7):901.

Mosmann T. Rapid colorimetric assay for cellular growth and survival: application to proliferation and cytotoxicity assays. J Immunol Methods. 1983;65(1-2):55-63.

Nurul Aini MN, Said MI, Nazlina I, Hanina MN, Ahmad IB. Screening for antiviral activity of sweet lemon grass (Cymbopogon nardus (L.) Rendle) Fractions. J Bio Sci. 2006;6(3):507-10.

Ocheng F, Bwanga F, Joloba M, Borg-Karlson AK, Gustafsson A, Obua C. Antibacterial activities of extracts from ugandan medicinal plants used for oral care. J Ethnopharmacol. 2014;155(1):852-5.

Oliveira MMM, Brugnera, DF, Cardoso MG, Guimarães LGL, Piccoli RH. Rendimento, composição química e atividade antilisterial de óleos essenciais de espécies de Cymbopogon. Rev Bras Plantas Med. 2011;13(1):8-16.

Panseira MR, Santos ACA, Paese K, Wasum R, Rossato M, Rota LD, et al. Análise de taninos totais em plantas aromáticas e medicinais cultivadas no Nordeste do Rio Grande do Sul. Rev Bras Farmacogn. 2003;13(1):17-22.
Riss TL, Moravec RA, Niles AL, Duellman S, Benink HA, Worzella TJ, Minor L. Cell viability assays. In: Sittampalam GS, et al. Assay Guidance Manual [Internet]. Bethesda (MD): Eli Lilly \& Company and the National Center for Advancing Translational Sciences; 2004. Available in https://www.ncbi. nlm.nih.gov/books/NBK144065/?report=reader

Schnitzler P, Neuner A, Nolkemper S, Zundel C, Nowack H, Sensch KH, Reichling J. Antiviral activity and mode of action of propolis extracts and selected compounds. Phytother Res. 2010;24(4):632.

Soares MO, Alves RC, Pires PC, Oliveira MB, Vinha AF. Angolan Cymbopogon citratus used for therapeutic benefits: nutricional composition and influence of solvents in phytochemicals content and antioxidant acticity of leaf extracts. Food Chem Toxicol. 2013;60:413-8.

Tang LI, Ling AP, Koh RY, Chye SM, Voon KG. Screening of anti-dengue activity in methanolic extracts of medicinal plants. BMC Complement Altern Med. 2012;12(3):1-10.

Verza SG, Kreinecker MT, Reis V, Henriques AT, Ortega GG. Avaliação das variáveis analíticas do método de Folin-Ciocalteu para determinação do teor de taninos totais utilizando como modelo o extrato aquoso de folhas de Psidium guajava L. Quím Nova. 2007;30(4):815-820.

Wagner H, Bladt S. Plant drug analysis: a thin layer chromatography atlas. 2 ed. Berlin: Springer Science \& Business Media; 1996.

Woisky RG, Salatino A. Analysis of propolis: some parameters and procedures for chemical quality control. J Apic Res. 1998;37(2):99-105.

Received for publication on $30^{\text {th }}$ January 2018 Accepted for publication on $04^{\text {th }}$ April 2018 